\title{
Narratives of the Portuguese Diaspora: Life, Literature, Cinema
}

\author{
Maria Helena Padrão \\ (helenapadrao@hotmail.com)
}

Isabel Rio Novo

Célia Vieira

ISMAI, Instituto Universitário da Maia

CELCC-CIAC

\section{DOI:10.5901/mjss.2014.v5n19p600}

\begin{abstract}
This project aims to understand the contexts of life of the people involved in this process (rupture, integration, opportunities, etc.) and, in parallel, study the literary and filmic fiction whose subject is the Portuguese diaspora, seeking to draw analogies and differences between the lived stories and fictional stories. Literature and film as the real modelling elements often have an anticipatory nature and therefore also instructive. "The fictional (...) works rather as a means of making imagery affordable to experience outside of their pragmatic function. The open spaces of pretence, the fictional compels the imagination to take one way, while at the same time, acts as a medium for its manifestation "(Iser, 1993).
\end{abstract}

Keywords: Fiction, Literature; Cinema; Diaspora; Portuguese

\section{Introduction}

This research aims to contribute not only to a better understanding in relation to the subjective experiences of "retornados" who constituted more than five hundred thousand individuals from the Portugal colonies and highlight memories and representations of this migrant population but also contribute to a better understanding of the past and present of this period of Portugal History.

To do this work which envisages three arts of telling the same elements and ideas - life, literature and cinema - we had to do the incursion through their epistemological questions: testimonies analysis; literary analysis and the filmography analysis such as intermedia adaptation questions.

Those questions were analysed because we intend to establish a parallelism between the three subjective narratives that emphasize the great thematic of the return during the revolutionary period April 1974 with the Portuguese colonies independence. In fact, many literary narratives about post-colonial period intend to give voice to those people to whom the return had represented a crisis period.

From the testimonies of returnees respondents, it's possible to note the complexity of building relationships, memories and representations. More than three decades later, we assist to a great silence about this thematic, and now we intend to hear the voice of those who were actors and victims of this process. We know that these individuals have reconstructed their past in different ways, ranging from the hurt of what was left behind, to the romanticizing of the past.

Many literary works have been designing and interpreting this period of recent history of Portugal. The novel gives voice to those people by the creation of a fictitious world which reflects their lost world.

We can refer Ana Sofia Fonseca (2009), Angola, Terra Prometida; Manuel Acácio (2009) A Balada do Ultramar; Khan Sheila (2009) Imigrantes Africanos Moçambicanos; Júlio Magalhães (2008) Os Retornados. Um amor nunca se esquece; Isabela Figueiredo (2009) Cadernos de Memórias Coloniais; Ricardo de Saavedra (1995, 2008).Os Dias do Fim; António Coimbra, Angola - horizonte perdido or Rita Garcia, S.O.S. Angola - os dias da ponte aérea. 
As we can see, only in the late 90's, early works appear relating the memory of experience Portuguese diaspora and the return. It's an upcoming narrative testimony that observes the lost of empire and the massive return in airlift as the image of a country flown.

But, our interest is the novel The Return (2011) from Dulce Maria Cardoso, who introduces an interesting regard about the exile which returned Portuguese people had suffered in the troubled period of independence former Portuguese colonies. This novel has also been adapted to another media.

In a broad sense, we call adapting the use of a previously formalized narrative as inspiration to produce a new narrative artifact. What characterizes adaptation is therefore a relationship between manifest and determining one or more narrative texts.

There is a long tradition of adapting literary narratives films (and later television), even going back to the beginnings of the seventh art. There are several reasons to justify the emergence of film adaptation of literary works, especially the fact that the first Mondays often find an inexhaustible source of well structured stories elapsing. As Marta Sousa summarizes: "The fact that the filmmakers were able to handle the language of film doesn't imply (necessary) the ability or inspiration for designing an original story, and the writers do not always have to present original ideas. In this case, using literature as a base is a way to keep production where the creativity of filmmakers, producers and writers do not follow the requirements of the film market." (Sousa, 2012: 20).

However, nowadays, due to the technological transformation of the media that we have attended and novel ways that originates, due to the multiplication and spread of new channels and media, we increasingly live in the middle of an indefinite circulation of fictions that rewrite, rework it and develop simultaneously in several directions not necessarily converging to the point of a narrative is increasingly less a text, a film, a cartoon, a musical piece, a video game, to be a little of all this and becoming inextricably. In 1988, his work in theoretical reflection on The Art of Romance, the Czech novelist Milan Kundera somehow foresaw this reality when noted: "Adaptations, transcripts, cinematographic, televised. Rewriting as zeitgeist. One day all last culture will be completely rewritten and completely forgotten behind his rewriting [...]" (Kundera, 2002:166)

Despite the proclaimed lack of studies on the film adaptation (McFarlane, 1996; Stam, 2005; Sousa, 2012) and the lack of general theoretical models that have been solved with various analyzes on particular cases, the reflection on the adaptation audiovisual narratives of literary works has to be guided by the understanding of adaptation as a creative process that requires transcoding intersemiotic, since it involves the conversion of a literary narrative in a semiotic polisystem. Indeed, while a literary narrative is constructed through verbal language, in a filmic narrative-verbal join photography, moving image, sound, sound effects ... As regards Linda Hutcheon, either literature and cinema can be considered immersive media, but is it differently: 'the narration mode (a novel) immerses us through the imagination in a fictional world; the visual mode (plays and films) immerses us through the perception of auditory and visual) (Hutcheon 2006: 22). That is to say that, while the literature has a conceptual nature, appealing to the imagination, the film has a perceptual nature, based on audiovisual languages, be captured by the senses. According to Robert Stam, "Adaptation (...) can be seen to an orchestration of discourses, talents, and tracks, the 'hybrid' construction mingling different media and discourses and collaborations" (Stam, 2005: 9).

Understanding this difference inherent in the nature of the media involved means accepting that a film adaptation is inevitably different from the literary work that gives it place. As much as the adaptation of a literary narrative film narrative (whether fictional or documentary character) presupposes the desire for aesthetic identification between the director and literary work, so that the imaginary intuition text can become sensitive perception on film, the director will always be a translator that reads, interprets and translates the literary narrative, not leaving much to put in the adaptation of his own imagination.

To this extent, the old debate about the faithfulness of the adaptation to the original literary, discredited today, tends to be replaced by the realization that the film adaptation lives in the match between the (re) invention of a pre-existing work and attempt to (re) against a previously intuited essence. The same is to say: A film adaptation is not faithful and never should be. So today, instead of comparing to the original exhaust and adaptation, at their points of convergence and divergence, as this convergence was the canon of excellence for adaptive practice, we consider adapting their own creative way, not pejorative coined with new names, such as reformatting, transcoding, reading, interpretation, remediation, intertextuality practice ...

As Robert Stam points out, 'adaptations' adapt to' changing environments and changing tastes, as well as to the new medium, with its distinct industrial demands, commercial pressures, censorship taboos, and aesthetic norms [...]. "(Stam, 
2005: 3) In the case of adaptation of a fictional literary narrative a documentary, it is urgent to understand that these changes joins the essential difference between an object of fictional and filmic record that is intended more or less real.

Adopting, among other possible types of adaptation, one that is presented by Geoffrey Wagner (1975) and recovered by Lydia Martin (2007), a documentary assumes therefore always necessarily a form of adaptation that they designate as comment, this is one that modifies some aspects of the original narrative, gives relevance to others and omitted others, or an adaptation that could be designate as an analogy, because it uses the original narrative only as a starting point, boasting numerous changes, additions and deletions of essential elements of the source text (Wagner 1975: passim; Martin, 2007: 68),

The theme of decolonization promoted several lusophone film productions, both fictional and documentary character. These productions reflect both the colonial conflict as the decolonization process and offer different perspectives, at various times in recent history, about how Portuguese society developed its relationship with Africa and the living testimonies of post-colonial reality.

After the April Revolution, with the recognition of the right to self-determination of the peoples of colonial territories, the filmography accompanies the redefinition of national identity imposed by the end of the Empire, while the filmmakers seek to register outside the studios, the historical reality (Costa. $s / d$ ). Within the documentary film, these audiovisual documents testify to the fracture of decolonization on both banks of migration: the present armed conflict and the chaotic exodus of people fleeing from the overseas territories and capture images of their arrival in the Portuguese capital, the cultural country political, economic and socially inept to perform this host. At the same time, the fictional film focuses mainly on the ideological rethinking of the democratic regime imposed from colonialism. After years of censorship, finally expresses negative view of Colonial War (if the film Farewell, My Return To The 1974, António-Pedro Vasconcelos), while firm a certain complicity with the liberation movements of the ex-colonies (case of the Demons of Alcacer-Kibir, 1977, José Fonseca e Costa). As noted Paulo Cunha (2003), although there are kilometres of film on the reality of colonial war and the conflicts arising from the claim of autonomy of the colonies, in the field of cinema, Portugal records failed to exorcise the ghosts of this collective memory, the point this researcher stated that 'there is censorship on the subject as fierce as before the revolution. "(Cunha 2003: 15). So after the 25th of April, for about a decade, the generation of the end of empire, in general, moves away from these uncomfortable subjects of the recent past, a political and economic context characterized by lack of interest in relation to Africa and by seeking rapprochement with Europe.

From the mid-80s and during the 90 s, there were the first film and the first novels that break the taboo of the colonial war: cinema, Goodbye Portuguese (João Botelho, 1985), once was a Ensign (Luís Filipe Costa, 1987), Killing Missing (Fernando Lopes, 1987), or Non Vain Glory of Command (Manoel de Oliveira, 1990), the Biggest Age (Teresa Villaverde, 1991), among others; in the novel, Elephant Memory and Knowledge of Hell (António Lobo Antunes, 1979 and 1980), The Murmuring Coast (Lidia Jorge, 1988), The Memory View Killing and Dying (João de Melo, 1977) among others. The theme of "returnees" continues to deserve less attention, although there are early attempts catharsis of this issue, that stands out the aforementioned fictional work Lidia Jorge, Pier of Picnic (1982) or, Alvaro Guerra, Café 25 April (1987) and, in the journalistic field, the story of Fernando Dacosta the returnees are changing Portugal (1984), then honored as the Grand Prix of the Portuguese Reportage Press Club.

It would be necessary to await the early 90s, to watch the first filmic productions that address the experience of the Portuguese who lived the process of decolonization. These early achievements seem to lie mainly in the exploration of memories of Africa and the antithesis between a past revived nostalgic way and a decadent gift. As is the case of the South (1993), Fernando Matos Silva, and especially the film Paradise Lost (1995), Alberto Seixas Santos, the first film in particular focusing on the problems of returnees from the former colonies. For some scholars, the productions that aim to romanticized and nostalgic representation of colonialism are part of a remoteness from the bellicose theme and denounce, the time, the difficulty still remains to assume the acts committed during the armed conflict and seeking a space possible coexistence between the three vertices of the problem: ex-colonized, returnees and ex-colonizers. It is against this nostalgic trend, resulting in products like television soap opera The Jewel of Africa (TVI, 2003-2004), manifested to some extent also in the film The Full Suit or looking for Alberto (Inês de Medeiros, 2002), which are imposed filmic productions such as adaptation of Margarida Cardoso the Murmuring Coast (2004), which seeks to recover from the novel by Lidia Jorge, the truth about the history of colonial war and expose the discrepancies between the colonizers and the history of history of colonization.

Only about 30 years after the arrival of the "returnees" is that it appears the breaking of silence about the traumatic experience of "return". The wave of books that focus returnees also reflected in film production, both building upon both the oral testimony of this experience as in historical documents finally made public. Therefore, the latest film production on 
this topic has taken a markedly documentary character. She highlight two documentaries that fall under the latest trends Portuguese documentary, which has sought inspiration on topics of their own country (Smith, 2010), contributing to the construction of the meanings of contemporary national history. Both the first, The Remains Returned or Empire (2002), Leandro Ferreira, with Dulce Lopes Cardoso and Luis argument, as the second, the movie Guns and Gear (2013), awarded the prize for Best Documentary at the farm edition of Festin - Itinerant Cinema Festival of Portuguese Language, Portuguese filmmaker Ana Delgado Martins, which records the return of 300,000 Portuguese in Angola, are constructed from the joint between archival footage, interviews, footage and historical research. In the opinion of the latter fulfilling itself daughter returned, this achievement is a contribution to a process of collective catharsis: "It's a very personal documentary and serving in some form of tribute to everyone who managed from scratch, rebuild itself, facing the void, fill the bags again, "but that still cherishes a heartache unresolved. (Martins, 2014).

The culmination of this opening movement of personal and public files on decolonization match, however, the television production of And Then Goodbye (2013). Over 26 episodes, this great production of BBC1, traces the historical portrait of the post-revolutionary Portugal, from the history of the returning families accommodated in a hostel in Lisbon. Tracking the characters from episodes of happiness lived in Africa and suddenly interrupted by the revolutionary upheaval, until their arrival in a state of grace, to Lisbon, and describing the successive stages of its (in) adjusting to Portuguese reality series crosses fiction and reality, subscribe to, for example, the fictional characters in films from the archives of television producer. But her television series extrapolated size and promoted a wave of real memory management, to give voice to other media, to all the witnesses who identify with the theme. Indeed, the series established a link of continuity with a radio show (Once and Again, Antena 1), with a blog and a facebook page, allowing the sharing of experiences and documents from persons who had lived through this period troubled in Portuguese history.

This reassessment of the history of Portugal in its relations with Africa integrates in XXI century a global context approach to African countries of the diaspora, driven both by the desire to establish economic and cultural cooperation as by the desire to overcome the ghosts of colonialism. So for Margarida Calafate Ribeiro, this literary and testimonial wave that has marked the Portuguese panorama 'also denounces, rightly or wrongly, that to realize the current Portugal has to make the return trip to Africa', because only then will possible to generate future: "Wounded, injured, guilty, but future, though." (Ribeiro, 2010).

In short, a period of almost forgotten until a stage reinvention of colonial memory and up to a recent phase of exposure, a number of records and the dramatic experiences of return, how the filmic record addressed the issue of decolonization clearly reveals the difficulty the country expressed in assimilating and write this episode in recent history.

This is the tragedy of the return, the feeling of no longer belonging to a place.

Dulce Cardoso, in The Return (2011) written from a postcolonial perspective, gives an account of silence that surrounds the 'retornados'. In this novel, the "return" is accompanied by the need to build a meaningful place because, in many cases, those migrants seem like refugees who bring with them, little more than living.

The Return, novel, and the documentary present some relevant aspects which are also present in the testimonies of this migrant group:

- The difficult experiences experienced by portuguese returned people through the regard of a teenager personage who relates the return from Angola to Lisbon

- The unknown portuguese reality. The imagined metropolis had no correspondence with real life. "The metropolis can not be like today we saw on the way that the taxi did, nobody would compel us to sing hymns of Saturday morning the city was so narrow and dirty with such narrow streets where it seems that do not fit. The roads were so many holes and so large that the bags fanned bars car [...]. No, the metropolis can not be seen as today." (Cardoso 2011:77)

Those "retornados" have different representations of Portugal as their homeland. One of them felt metropolis as a memory place of life, the other, already second generation, born in the former colonies, have an imagined homeland representation of the metropolis.

- In those cases, what is analysed, is the return to the Portuguese homeland, a country that over their lives is the unifying motif of different diversities. The portuguese homeland that portuguese migrants had keeping in heart 
and had transmitted to their children. It was the country that was always present in their lives, throughout basic education, through mandatory single textbook in all schools of the empire.

And if it is true that this metropolis with which the "true" returned never stopped dreaming, had received them as they were foreign, the same can be said about those who returned to this unknown country, that was strange to them, and received the same attitude from the host people. So, these migrants are prisoners of the displacement.

The dialogue between fiction (literature or Cinema) and real life is a quasi-autobiographical option. Experiences and difficulties of integrating and social acceptance that many who passed former empire nicknamed erroneously as "returned".

In reality, more than socially subtle ostracism, many of these women and men felt they were embarking into a voyage of an identity exile, because they were neither from Angola, their lost homeland, neither portuguese citizens (besides the identity card).

We can perform that those "returned" live throughout the lost paradise and the hostage exile.

When they were in Angola they think they belonged there, and they loved this land, because of the climate, the conviviality, the abundance, the solidarity.

The rupture was felt like a fracture in their lives, because in their minds they could live there after the independence.

"I confess, I always thought, naively, that everyone could live there after independence." (Domingos, engineer, 60 years old)

"Before the shots have begun the future would always be better. Now everything is different and therefore we do not already have affairs to speak. Neither plans. The father will not work no longer, there is no longer school and the neighbours are already all gone." (Cardoso, 2012: 9)

The statements which are recorded here reveal the memory of the events that are experienced abruptly, causing a sort of post traumatic stress that only time can heal. The memory treated in this work essentially concerns to what Giddens et al. (1994: 63) propose:

"Memory is thus an active, social process, which cannot merely be identified with recall. We continually reproduce memories of past happenings or states, and these repetitions confer continuity upon experience."

"The mother insists that the father can serve up roast beef. The food will spoil, she says, this heat cable of all, a few hours and the meat begins to green, to put on the glacier becomes dry as a sole. The mother speaks as if tonight might not go catch the plane to the metropolis, as if tomorrow we could eat with bread the leftover pot roast, on the high school playground. Let me, woman. By removing the platter, the father knocks the bread basket. The mother straightens it and straightens the crusts so carefully as, every morning, she straightens the pills sorts before taking them. The father was not well before it has begun. These are the shots that we can hear in our neighbourhood and we can see our four bags by closing the room." (Rui, The teenager of the novel)(Cardoso, 2011: 1).

Or in this text:

"Uncle Ze will lead us to airport. The father goes there after. After killing the Pirate and after throw fire to the house and to lorries. I do not believe father can kill Pirate. I also don't believe father can throw fire to the house and to lorries." (Rui, the teenager of the novel) (Cardoso,2012: 8).

"I came here in airlift. I stayed there, until I realized I could no longer live there. From the house in front of mine, which belonged our friends who were MPLA movement, I saw our house to be razed by mortars."(Mario, commercial, retired,76 years old)

\section{- feeling of lost and sadness}

"Before the shots have begun the future would always be better. Now everything is different and therefore we do not already have affairs to speak. Neither plans. The father will no longer work, there is no longer school and the neighbours are already all gone. (Cardoso, 2012: 9)

\section{- nostalgia of lost homeland}

"The father never speaks about metropolis, the mother has two lands but not the father. A man belongs to the place which feeds him, unless you have a ungrateful heart, so it was what father says when asked if he miss the metropolis. (Rui, the teenager of the novel) (Cardoso, 2011: 12) 
- feeling of marginalization by the host metropolis motivated by the fear of the effects of this migrant group

"I'm Angolan. I was born there, I belong to the fifth generation. My mother's ascendance has black blood. When I came here (...) everyone called me "retornada", until the family looked at me like an explorer of blacks. I was "retornada". I Could not stand here, in Portugal and I went to Brazil. I have a debt of gratitude to the Brazilian people, who always treated me very well." (Emília, teacher, 58 years old)

\section{- absence of sense of identity in relation to an austere figure of European colonizers in Africa}

"When I was in Angola, I treated the daughter of the laundress who was alcoholic. I always treated her like a daughter. She was studying in college Nuns with my daughter. I payed his education. There, white and black, we were a family." (Ester, house-wife, 76 years old)

As we can verify, they manifest the feeling of distancing regarding to the abuse of power by the white over black. We also verify the positive representations of he "l", representations of the "other", and representations of the "spaces between" We also observe the feeling of how much affective were the relationship between them (white and black).

\section{- feeling of dissimilar experiences of the rest of portuguese population}

"When I went to Angola I was very young, 15 years old. I went with my family, my parents, three brothers and a sister. My parents had no work and had no food to give us. It was because of the Second Great War. We were poor people. In the voyage, we were in the basement of the boat, in poor conditions, yes. And when we got there, we had nothing. Friends had cost us. Those were hard times: terrible weather, strange food, the dirt roads and the tall grass, malaria and no money. Bad times"(Mário, commercial, retired, 76 years old)

\section{- feeling of positive presence of the portuguese in Angola}

"When I arrived in Angola, I worked very much, I never had neither Saturday nor Sunday. Every time was work time. Portuguese people built great towns, and when we were there, there was abundance of food and space, conviviality and mutual aid." (Alberto, HR director, retired, 78 years old)

\section{- the representation of the metropolis to those who didn't know Portugal}

"The metropolis has to be like this until the hotel has an elevator lined in velvet banquette. Portugal is not a small country, it was what was written on the map of the school, Portugal is not a small country, it is an empire from Minho to Timor. (Rui, the teenager of the novel). (Cardoso, 2011: 30)

- idealizing white communities in contact with blacks

Their testimonies reveal a past guided by cohabitation between whites and blacks, strong friendships, a lost paradise of freedom spaces, great cosmopolitan cities of idyllic images that remain in their minds, filtered by a tragic return.

These places, with relevant values, are also ways of keeping the past alive, reflecting personal and collective perspectives of the past.

It's the memory that brings issues inherent in portuguese contemporary, especially the feeling of inadequacy of people within a period of depression of the portuguese empire, a delusion involving returnees who know about the irreversibility of the fracture situation, the experience of exile that leads to painful experience of homeland loss and the feeling of being out of place.

"The achievements of exile are permanently undermined by the loss of something left behind forever" (Said 2003: 46).

In The Return (Cardoso, 2011), we can find the elements that also emerge from the collected oral testimonies: feeling inadequate to the metropolis; the grief of the loss; a sense of injustice and perplexity; a feeling of powerlessness.

The reconstruction of the past had revealed important throughout the various speeches. Experience in Angola observes that those who expose their post-memories had been quiet but not dead. Therefore, it's so important this space given to a people in transition, between walls or in the diaspora. This migrant people have a lifetime to tell.

And all testimonies are unanimous on the idea of Emília (teacher, 55 years old):

"It is obvious that the colonies must not exist, but what about us, why we had to leave?

The same idea we can find in other testimonies in the Leandro Ferreira video documentary done by adaptation from a Dulce Cardoso and Luis Lopes argument: 
"Lost. Above all lost. In a land that is no longer theirs, running away from violence and confusion, they arrive in a small country with no room for them, a country they had heard about, but never known: Portugal." (Ferreira; Cardoso \& Lopes, 2002).

\section{Method}

In this research we used a qualitative approach that provided well-grounded narratives.

Interviews were performed between May 2012 and February 2013. Such interviews were composed of a set of predetermined questions and in accordance with the objectives of the work and problems.

The interviews were conducted presencially and face to face, and all interviews had the same type of recording. It was also guaranteed the confidentiality. The excerpts that are transcribed here are only identified with a proper name.

We opted to choose a segment of individuals who have had returning experience, when occurred decolonization in Angola after the portuguese revolution of April 1974. The group of respondents in this investigation relates to persons aged over 50 years, yet this group is subdivided into two: one formed by individuals who emigrated to Angola in the decades of 1950-60-70, the other formed by individuals who were born in Angola, or who, having been born in metropolis, have passed infancy in Angola, having no memory of the metropolis as a homeland.

We also used a comparative analysis to establish similar elements between testimonies, literary narrative and documentary. Literature has a conceptual nature, appealing to the imagination; the film has a perceptual nature, based on audio-visual languages. In this sense we opted to analyse similar themes on life stories and those media using a comparative method.

\section{Discussion}

Main conclusions of the study:

- Before arriving Portugal, most returned people expected to find a sunny, warm, beautiful homeland with a hospitable people. But, to contrast, they arrived to a country also under a social and political crisis.

- The list of representations of Portugal for these migrants, after living in Portugal, includes the perceived feelings of the portuguese people.

- $\quad$ The reasons for the feeling of belonging to anywhere is essentially the certitude of irreversibility of return to Angola and the confrontation of Portugal as a strange country without feeling an "at home" sensation.

- The motives for not wanting to stay in Portugal in pos-independence of Angola encompass the feeling of a nonacceptance by the host population.

- Individuals born in the colonies were called "retornados" and they felt a kind of marginalization by the host metropolis

- The memories of returned people are an important document which is necessary to study.

- $\quad$ Difficulty of returned portuguese people in assimilating and writing this episode in recent history.

- The history of a country must be done with the inventory of documents: story lives, fiction narratives, films, documentaries or videos.

\section{References}

Abrantes, José Mena (1995). «Imagens desfocadas», in Cinemas de África, Lisboa: Cinemateca Portuguesa e Culturgest. Acácio, Manuel (2009). A Balada do Ultramar. Lisboa: Oficina do Livro.

Buescu, Helena (2008). Emendar a morte. Pactos em literatura. Porto: Campo das Letras.

Cardoso, Dulce Maria. (2011). O Retorno. Lisboa: Tinta-da-China.

Costa, José Filipe (s/d). «A revolução de 74 pela imagem: entre o cinema e a televisão. Princípios para a compreensão do cruzamento dos dispositivos televisivo e cinematográfico entre 1974 e 1976». In www.bocc.ubi.pt 
Cunha, Paulo (2003). Guerra Colonial e Colonialismo no Cinema Português. in Estudos do Séc. XX - Colonialismo, Anticolonialismo e Identidades Nacionais, revista do CEIS20, Coimbra, 3, 2003, pp. 185-208.

Faria, Almeida. (1987). Cavaleiro andante. Lisboa: Caminho.

Ferreira, Leandro; Cardoso, Dulce; Lopes, Luís (2002). The Ones That Came Back. Mar Filmes Ed. In http://www.cinept.ubi.pt/pt/filme/8619/Os+Retornados+ou+Os+Restos+do+Imp\%C3\%A9rio\#sthash.h60VLlhB.dp uf

Figueiredo, Isabela, ( 2009). Cadernos de Memórias Coloniais. Lisboa: Angelus Novus Fonseca, Ana Sofia (2009). Angola, Terra Prometida. Lisboa: Esfera dos Livros

Khan, Sheila. (2011). O 'Sul' mesmo aqui ao lado: Cartografias identitárias abissais do póscolonialismo português. In: BRANDÃO, Ana e RODRIGUES, Emília (eds.). Intersecções identitárias. Famalicão: Húmus, 2011, p. 49-64.

(2009a). Imigrantes africanos moçambicanos. Narrativa de imigração e de identidade e estratégias de aculturação em Portugal e na Inglaterra. Lisboa: Colibri.

. (2009b). A espessura do exílio em A balada do Ultramar. In: Revista Teia literária. Rio de Janeiro: PUC, 311329.

(2006). Identidades sem chão. Imigrantes Afro-Moçambicanos: Narrativas de vida e identidade e Percepções de um Portugal pós-colonial. In: Luso-Brazilian Review, 43:2, University of Wisconsin: 1-26.

Leite, Ana; Khan, Sheila; Falconi, Jessica; Krakowka, Kamila (2012). Nação e narrativa pós-colonial. Volume de entrevistas. Lisboa: Colibri (em revisão final para publicação).

Lourenço, Eduardo. (2011). A Europa desencantada. Para uma mitologia europeia. Lisboa: Gradiva.

. (1976) "Retrato (póstumo) do nosso colonialismo inocente I",Critério, 2, Janeiro, pp. 8 -11 e 63.

. "Retrato (póstumo) do nosso colonialismo inocente II", Critério, 3, Janeiro, pp. 5-10.

Machado, Bruno Ricardo Delgado (2011). Os filhos dos "retornados": a experiência africana e a criação de memórias, pósmemórias e representações na pós colonialidade. Dissertação de mestrado, Universidade de Lisboa.

Magalhães, Júlio (2008). Os Retornados. Um amor nunca se esquece. Lisboa: Esfera dos Livros.

Martins, Ana Delgado (2014). «Realizadora Ana Delgado Martins afirma que falta catarse ao tabu da descolonização», inhttp://online.jornaldamadeira.pt/artigos/realizadora-ana-delgado-martins-afirma-que-falta-catarse-ao-tabu-dadescoloniza\%C3\%A7\%C3\%A30

Matos-Cruz, José de (1999). Cais do Olhar. O Cinema Português de Longa Metragem e a Ficção Muda. Lisboa, Cinemateca Portuguesa - Museu do Cinema.

Ramos, Jorge Leitão (1989). Dicionário de Cinema Português 1962-1988, Lisboa, Caminho.

Ribeiro, Margarida Calafate (2004). Uma História de Regressos - Império, Guerra Colonial e Pós-Colonialismo, Porto: Afrontamento.

Ribeiro, Margarida Calafate (2010). «Margarida Calafate Ribeiro sobre «Caderno de Memórias Coloniais»», inhttp://angnovus.wordpress.com/2010/02/18/margarida-calafate-ribeiro-sobre-\%C2\%ABcaderno-de-memoriascoloniais $\% \mathrm{C} 2 \% \mathrm{BB} /$

Saavedra, Ricardo de $(1995,2008)$.Os Dias do Fim. Lisboa: Casa das Letras.

Salvato Teles de Menezes (1985). 10 Anos de Teatro e Cinema em Portugal (1974-1984), Lisboa, Editorial Caminho, Colecção Nosso Mundo

Said, Edward (2003). Reflexões sobre o exílio e outros ensaios. Trad. Pedro Maia Soares. São Paulo: Companhia das Letras.

Santos, Boaventura de Sousa (2001). "Entre Próspero e Caliban: colonialismo, pós-colonialismo e inter-identidade", in Maria Irene Ramalho, António Sousa Ribeiro (org.), Entre Ser e Estar - Raízes, Percursos e Discursos da Identidade, Porto: Afrontamento.

Soares, Ana Isabel (2010). «Nem Velho nem Novo: Outro Documentário Abordagem das Tendências do Documentarismo Português no Início do Século XXI». In http://repositorio.ipl.pt/bitstream/10400.21/413/1/ana_soares.pdf

Teixeira, Rui de Azevedo (1998). A Guerra Colonial e o Romance Português, Lisboa, Notícias Editorial. 